\title{
Cutaneous Melanoma pM1 TNM Finding v7
}

National Cancer Institute

\section{Source}

National Cancer Institute. Cutaneous Melanoma pM1 TNM Finding v7. NCI Thesaurus.

Code C88395.

Cutaneous melanoma with detectable evidence of distant metastases. (from AJCC 7th Ed.) 